\title{
Community Empowerment Through Homegrown Medicinal Plants and The "Wedang Uwuh" Herbal Beverage Cultivation in Seketi Hamlet
}

\author{
Juliani Pudjowati, Thariq Abdurrahman*, Enjelita Putri Pratiwi, \\ Rizky Nugraha Baqi, Anggun Kumala Syafitri
}

Fakultas Ekonomi dan Bisnis, Universitas Bhayangkara Surabaya, Jl. Ahmad Yani No. 114 Ketintang, Surabaya, Indonesia, 60231

Correspondence: Thariq Abdurrahman (kknubhara2020.20@gmail.com)

Received: 10 January 2021 - Revised: 18 April 2021 - Accepted: 24 April 2021

\begin{abstract}
Rural community empowerment is an effort to develop independence and community welfare through the improvement of knowledge, attitudes, skills, behaviour, abilities, awareness, and resource utilization. This is carried out by establishing policies, programs, activities and assisting with the problems related to the priority needs of the community to increase community activities through the cultivation of homegrown medicinal plants. The homegrown medicinal plants (TOGA) are traditional medicinal plants. These medicinal plants are used for making Wedang Uwuh. The ingredients consist of various types of spices namely: ginger, cloves, nutmeg, lemongrass, cardamom, cinnamon, sappanwood, and rosella. The method of implementation used is through the diffusion of knowledge and direct practice. These activities were carried out for the residents of Seketi Hamlet. The results of the activities that have been carried out in Seketi Hamlet are as follows: the community gets insight into TOGA plants; people acquire skills in how to process TOGA into Wedang Uwuh herbal beverage which can help increase endurance (immunomodulators) to protect against Covid-19 pandemic; adding or increasing community activities through the use of house yards as TOGA growing media. Therefore, it is necessary for the Head of Seketi Hamlet to consider doing several things, namely the provision of advanced programs via entrepreneurship training to produce superior products from TOGA yields, and community cooperation in the continuous care of the "Seketi Hamlet Health Garden" for long term benefits.
\end{abstract}

Keywords: Community empowerment, TOGA, herbal medicine, Wedang Uwuh

Citation Format: Pudjowati, J. Abdurrahman, T., Pratiwi, E.P., Baqi, R.N., \& Syafitri, A.K. (2021). Community Empowerment through Toga and The "Wedang Uwuh" Herbal Beverage Cultivation in Seketi Hamlet. Journal of Community Practice and Social Welfare, 1(2), 1-15. 


\section{INTRODUCTION}

Seketi Hamlet is located in Jatidukuh Hamlet, Gondang District, Mojokerto Regency, at a distance of approximately $30 \mathrm{~km}$ from Mojokerto City. The Hamlet is divided into four neighbourhoods from the north to the south. The population of this Hamlet is sufficiently solid with 221 registered family cards. The majority of Seketi Hamlet residents works as farmers, ranchers, and farm labourers. The Hamlet is located in the highlands where the soil is fertile. Lands within the vicinity of Seketi is suitable for various types of plants such as rice, sugar cane, corn, cassava, and various homegrown medicinal plants (TOGA). Because the majority of Seketi residents are farmers, they have developed a close bond and deep social connection with each other. Hence, they generally embrace a familial culture. (Damsar and Indrayani, 2016).

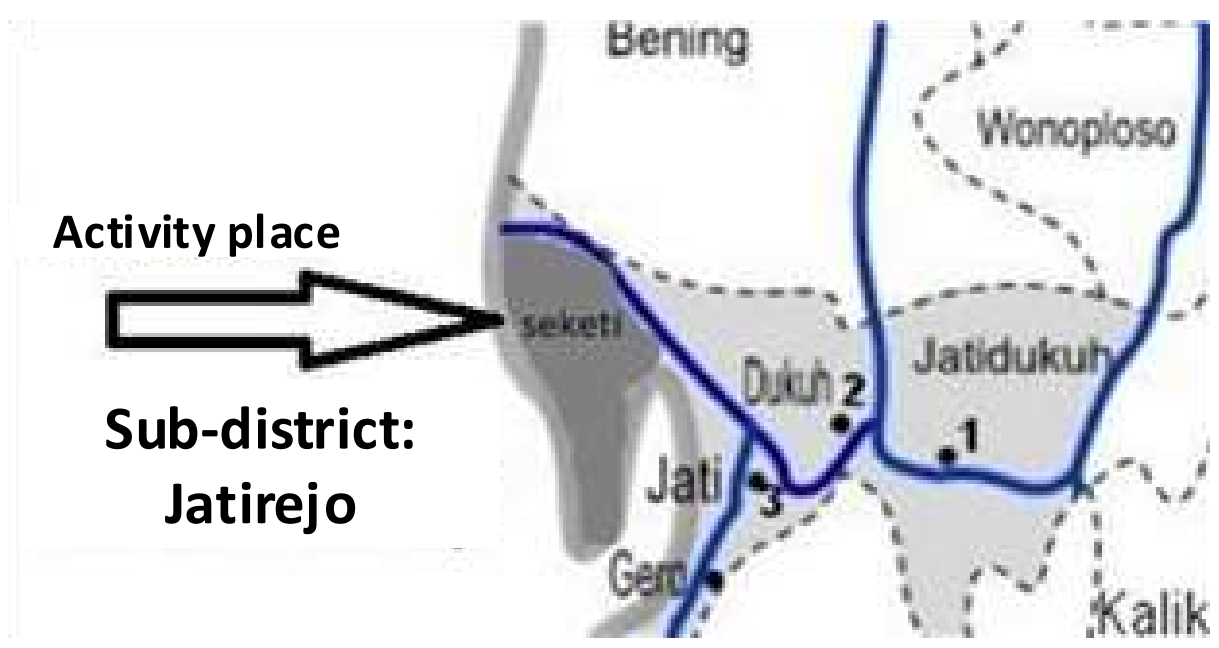

Figure 1. Geographical location of Seketi Hamlet

Hamlet Community Empowerment is an effort to develop the independence and welfare of rural communities by improving knowledge, character, skills, behaviour, abilities, awareness, and resource utilization through the establishment of policies, programs, activities and assisting with the problems related to the priority needs of the community (Damanik, 2019). The establishment of community empowerment in TOGA management is an effort to increase knowledge relating to the utilization and processing of TOGA. Harjono (2017) states that stems, leaves, seeds and roots are plants parts that are useful for medicinal purposes. In addition, Patola (2018) and Kusuma (2016) argues that TOGA has other benefits apart from being a medicine namely; as nutritional supplements, ingredients in spice cooking or seasonings, and as aesthetic enhancements. 
Based on a handbill Numbered: HK.02.02./IV.2243/2020, concerning the use of traditional remedies for health maintenance, disease prevention, and health care, the use of traditional medicinal ingredients during a public health emergency and/or The Coronavirus Disease (Covid-19) pandemic, processed TOGA is designated as herbal beverages that can increase immunity (immunomodulators) (Ministry of Health, 2020).

The use of medicinal plants in Indonesia has lasted for thousands last year. In the mid-17th century, a botanist, Jacobus Rontius (1592-1631), announced the benefits of herbs. This is written in a book titled De Indiae Untriusquere Naturali et Medica. According to Widaryanto (2018), simplicia medicinal plant parts are divided into eight groups, namely herbal simplicia, roots, leaves, flowers, fruit, seeds, rhizomes, and barks. Several types of simplicias, such as seed, fruit, and bark simplicias can be used for making traditional beverages such as Wedang Uwuh.

Quoting from Tribunnews, Wedang Uwuh is a type of herbal beverage with many healthy properties. This is because the ingredients consist of various types of medicinal plants in the family. Wedang Uwuh is useful for treating ailments such as coughing, colds, flatulence, aches and pains, and as a general refreshment.

Wedang Uwuh originates from Yogyakarta, Imogiri District, Bantul. In Javanese, wedang translates to beverage, while uwuh translates to waste. Waste beverage does not mean waste-based beverages, but drinks that consist of various types of medicinal plants, namely ginger, sappanwood, cloves, cinnamon, nutmeg, lemongrass leaves, cardamom, rock sugar, and rosella.

\section{METHOD OF IMPLEMENTATION}

In order to achieve the expected results, this activity is carried out through community empowerment, diffusion of knowledge, and hands-on practice. The implementation method and Student Effective Working Hours (JKEM) are the accumulation of the amount of program hours implemented by students participating in Community Service Program $(\mathrm{KKN})$. The implementation of JKEM was carried out by Group 20 of Thematic KKN students for 20 hours. The details are presented in Table 1 as follows. 
Table 1. Method of implementation, activity, and JKEM

\begin{tabular}{cccc}
\hline No & Method & Activity & JKEM \\
\hline 1 & Knowledge Diffusion & $\begin{array}{c}\text { Organizing socialization through } \\
\text { community empowerment programs } \\
\text { regarding the planting and use of TOGA }\end{array}$ & 1x60 minutes \\
& &
\end{tabular}

Organizing socialization regarding the $1 \times 60$ minutes making of Wedang Uwuh herbal drink

$2 \quad$ Practice

Construction of Seketi Hamlet Health $17 \times 60$ minutes Garden.

Organization of "Wedang Uwuh" herbal $1 \times 60$ minutes beverage production training.

\section{Activity participants}

Participants of this activity mostly consisted of Seketi Hamlet residents who collaborated and took part in the activities of planting media construction and TOGA planting. The main targets of participation for these activities are youth organizations and the average Seketi residents. The main targets of activity participation for the socialization of the benefits of TOGA and the production of Wedang Uwuh herbal beverage are housewives and the elderly of Seketi Hamlet.

\section{Technical implementation of activities}

The first activity carried out was the construction of planting media and methods of TOGA planting. Materials and tools used in these activities are as follows:

Tools:

1) Long bamboos $60 \mathrm{~cm}(25 \mathrm{pcs})$

2) Large decorative rocks (2 pack)

3) Small decorative rocks (2 pack)

4) Hoe and trowel

5) Bendrat wires (rebar wire)

6) Pallet wood fence $2.5 \mathrm{~m}$ ( 2 stalks) and $5 \mathrm{~m}$ (1 stalk)

7) Swab wood $5 \mathrm{~cm} \times 7 \mathrm{~cm}$ thickness with $1.8 \mathrm{~m}$ tall (2 stalks)

8) Swab wood $5 \mathrm{~cm} \times 7 \mathrm{~cm}$ thickness with $1 \mathrm{~m}$ tall (5 stalks) 
9) Crowbar

10) Concrete nails 2 “( $10 \mathrm{pcs})$

11) Wood nails 3" (15 pcs)

12) Name plank "Seketi Hamlet Health Garden" $80 \mathrm{~cm} \times 110 \mathrm{~cm}$ (2 pcs)

13) Name plank for plants (9 pcs)

14) Black paint spray cans (2 pcs)

15) Manure (10 kg)

16) Rice husk ( $2 \mathrm{~kg})$

17) Sticker for bane plank "Seketi Hamlet Health Garden"

18) Plant wiring $1 \mathrm{~m} \times 15 \mathrm{~m}$

Materials for homegrown medicinal plants (TOGA):

1) Green binahong (Heartleaf maderavine madevine)

2) Red binahong

3) Ginseng

4) Galangal

5) Fragrant pandan

6) Roselle flower

7) Green lemongrass

8) Red lemongrass

9) Green betel

10) Curcuma

11) Cinnamon

The methods of TOGA planting and making planting media (Figure 2) is as follows:

1) First, clean and measure the area of any potential land.

2) Determine planting area according to the existing plan, then install TOGA fences in the predetermined area.

3) Loosen the soil around the area for planting media.

4) Remove the plants from the poly bags and transfer it into the prepared soil.

5) Mix the fertilizer and husks with the soil to create the planting medium.

6) Install name planks as markers for plant types.

7) Next step is to decorate the plants with decorative rocks.

8) Lastly, install previously prepared name plank for "Seketi Hamlet Health Garden." 


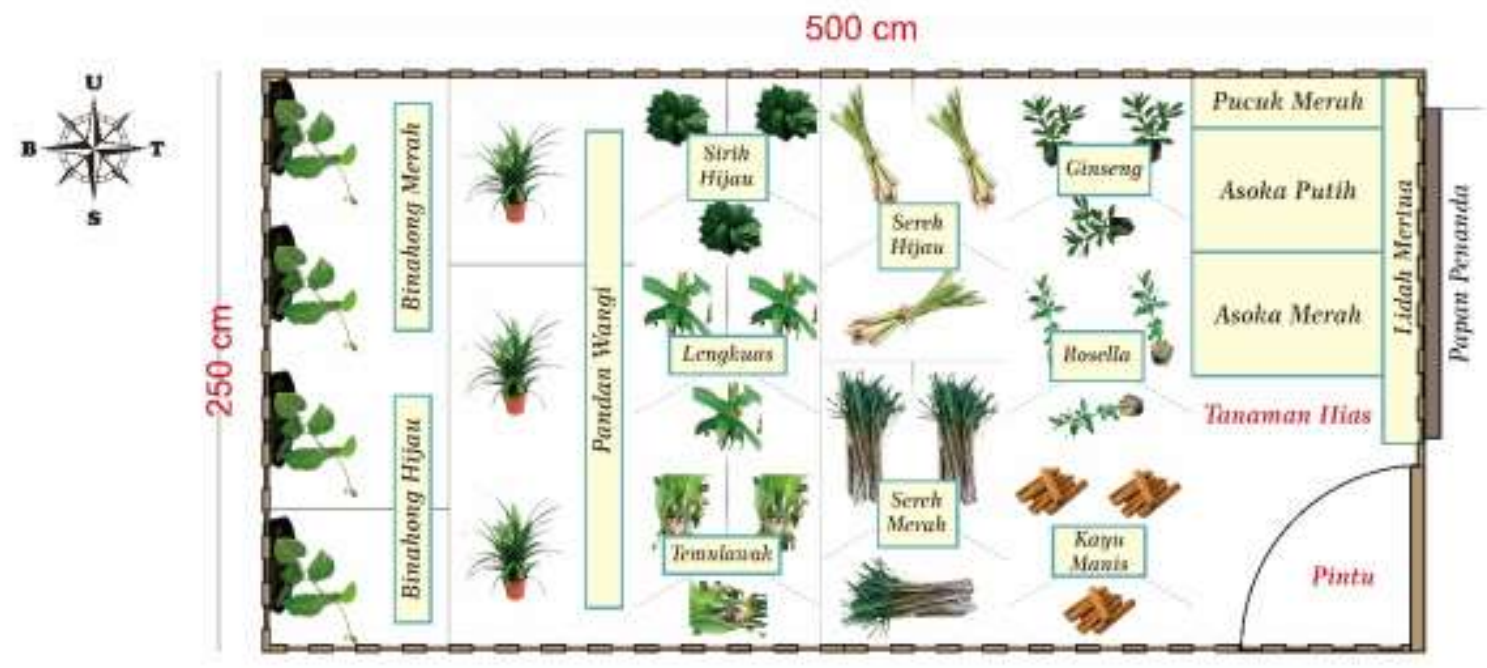

Figure 2. Design sketch for TOGA planting location in Seketi Hamlet health garden

Location for the TOGA planting plan of Seketi Hamlet Health Garden was carried out in Seketi Hamlet, to be precise, behind a Waste Bank. The plan shows that there are eleven types of TOGA grown in Seketi Hamlet, namely: ginseng, roselle, cinnamon, green lemongrass, red lemongrass, green betel, galangal, ginger, pandan, red binahong, and green binahong. The second activity is the socialization of the benefits of TOGA and the production of Wedang Uwuh herbal beverage. The materials and equipment used in this activity are as follows:

Materials:

1) Dried clove

2) Dried nutmeg leaves

3) Dried lemongrass leaves

4) Rock sugar

5) Ginger

6) Dried cardamom

7) Dried cinnamon

8) Sappanwood

9) Dried roselle 
Tools:

1) Cup

2) Flask

3) Plastic gloves

4) Plastic Ziplock

5) Plastic cup

How to make and serve Wedang Uwuh herbal drink (Figure 7):

1) Dry all ingredients beforehand.

2) Crush the ginger and put in into a cup.

3) Put other ingredients into a glass and fill with warm water.

4) Close the cup and leave it for three minutes.

5) The beverage is ready to serve.

\section{RESULT AND DISCUSSION}

Community service activities were carried out in Seketi Hamlet, Jatidukuh Village, Gondang District, Mojokerto Regency. These activities lasted for nine days, from 14th of November to 12th of December 2020. The activities were held at the end of every week, namely Saturdays and Sundays. The main activities of the service were community empowerment through the socialization of healthy lifestyles in the era of Covid-19 pandemic.

\section{A. Plant types}

According to the results from a survey conducted in Seketi Hamlet, TOGA planting had not yet been implemented in the hamlet. The types of plants grown by the group are listed in Table 2 . 
Table 2. Types of homegrown medicinal plants in Seketi Hamlet

\begin{tabular}{llcl}
\hline No & Plant Types & Amount & Efficacy \\
\hline 1. & Green Binahong & 3 & Lowers blood sugar to optimal levels and keeps blood \\
& & sugar levels stable in people with Diabetes Mellitus. \\
2. & Red Binahong & a) Treats burn injuries and ulcers. \\
& & b) Great for heart health and prevents cancer. \\
& c) Restores stamina and prevents diabetes. \\
& d) Treats gouts and anemia. Increases Appetite and \\
&
\end{tabular}

3. Ginseng

4. Galangal

5. Fragrant pandan

6. Rosella

7. Green Lemongrass

8. Red Lemongrass
3 a) Reduces inflammation.

b) Relieves stress.

c) Boosts the immune system.

d) Prevents premature ejaculation.

e) Prevents aging.

3 a) Alleviates joint pain.

b) Increases male fertility.

c) Reduces blood sugar levels and cholesterol.

d) Treats respiratory problems.

3 a) Relieves fever. People with fever often prefers to drink warm beverages.

b) Reduces pain.

c) Relieves stomach cramps.

d) Detoxifies the body.

e) Helps overcome Insomnia.

f) Increases appetite.

g) Relieves rheumatic pain.

3 impedes the absorption of saturated fatty acids and lowers triglycerides levels and bad cholesterol (LDL) in the body.

3 a) Source of antioxidant.

b) Detoxifies the body.

c) Reduces risk of cancer.

d) Keeps digestive system healthy.

e) Helps reduce weight.

f) Helps reduce enxiety.

3 a) Prevents cancer.

b) Herbal medicine.

c) Medicine for indigestion.

d) Detoxifies. 


\begin{tabular}{lll}
\hline No Plant Types & Amount & Efficacy \\
\hline
\end{tabular}

9. Green Betel

10. Curcuma
3
Relieves inflammation in the throat.

Stimulates the production of bile in the gall bladder, thereby helping improve digestive function. By consuming it regularly, various digestive problems can be resolved including bloating, gas problems and dyspepsia.

11. Cinnamon

3

a) Prevents blood clots, reduces blood sugar levels, and lowers the risk of heart disease.

b) Improves brain function, improves digestion, and protects against cancer.

Table 2 shows, that there are eleven types of plants that can be planted in the Seketi Hamlet area, namely: green binahong, red binahong, ginseng, galangal, fragrant pandan, Roselle, green lemongrass, red lemongrass, green betel, ginger and cinnamon. There are three types of plants for each arable media or land (Mindarta and Bebet, 2015).

\section{B. Delivery of material}

This activity was carried out by community service group 20 in Seketi Hamlet, Jatidukuh Village, Gondang District, Mojokerto Regency. The material is delivered through socialization. Socialization was carried out through the distribution of drafts containing text and pictures (picture 5). Presentation of material on the benefits of planting TOGA for the production of herbal beverages was given during the socialization. The target demographic of the activity is the Seketi Hamlet residents. During the activity, the community service group explained the benefits of TOGA as a herbal beverage (Wedang Uwuh) for medical treatments. This activity is expected to be a guide and source of information for the Seketi community, in the hope that Wedang Uwuh can be applied as a general medicine to treat various diseases.

To support the socialization process, implementers distributed questionnaires. The questionnaires were conducted before and after the presentation of the material. Questionnaires given after material presentation is an evaluation of the understanding and interest of the Seketi community in the use of garden plants for treatment. Evaluation is also carried out after material presentation to determine the amount of public understanding and 
interest in the use of garden plants for treatment. The questions asked in the questionnaire as well as the answers given by residents of Seketi Hamlet are shown in Table 3.

Table 3. Average results of questionnaire for residents of Seketi Hamlet, Jatidukuh Village, Gondang District, Mojokerto Regency

\begin{tabular}{|c|c|c|}
\hline No & Questions & Answers \\
\hline 1 & $\begin{array}{l}\text { Are you aware of the definition of } \\
\text { TOGA? }\end{array}$ & $\begin{array}{l}\text { Some residents of Seketi Hamlet have } \\
\text { knowledge of homegrown medicinal plants, but } \\
\text { there are also many residents who do not own or } \\
\text { plant them. }\end{array}$ \\
\hline 2 & $\begin{array}{l}\text { Have TOGA ever been implemented in } \\
\text { Seketi Hamlet? }\end{array}$ & $\begin{array}{l}\text { Joint planting of homegrown medicinal plants } \\
\text { have never been carried out in Seketi Village. }\end{array}$ \\
\hline 3 & $\begin{array}{l}\text { In your opinion is it feasible for all } \\
\text { residents of Seketi Village to own } \\
\text { TOGA? }\end{array}$ & $\begin{array}{l}\text { Very feasible considering the benefits and } \\
\text { properties of homemade medicinal plants can } \\
\text { also be useful for everyday life and can used to } \\
\text { treat ailments. }\end{array}$ \\
\hline 4 & $\begin{array}{l}\text { Are you familiar with Wedang Uwuh } \\
\text { herbal beverage? }\end{array}$ & $\begin{array}{l}\text { A number or residents are not familiar with } \\
\text { Wedang Uwuh herbal beverage. }\end{array}$ \\
\hline 5 & $\begin{array}{l}\text { According to you, is sustainable } \\
\text { production and selling of Wedang Uwuh } \\
\text { feasible? }\end{array}$ & $\begin{array}{l}\text { Very feasible for sustainable production and can } \\
\text { add into the resident's skillset. }\end{array}$ \\
\hline 6 & $\begin{array}{l}\text { If it is to be marketed, how much do you } \\
\text { think Wedang Uwuh should be priced } \\
\text { per sachet? }\end{array}$ & $\begin{array}{l}\text { Wedang Uwuh price range per sachet } \\
\text { should be around IDR } 3,000 \text { - IDR 4,000, if } \\
\text { Ready to drink can be sold within } \\
\text { the price range of IDR } 5,000 \text { - IDR } 7,000 \text {. }\end{array}$ \\
\hline 7 & $\begin{array}{l}\text { According to you, do you think Wedang } \\
\text { Uwuh has economic value for the } \\
\text { community itself? }\end{array}$ & $\begin{array}{l}\text { Wedang Uwuh herbal beverage can be of } \\
\text { economic value to the residents of Seketi } \\
\text { Hamlet due to the cheap price of the beverage } \\
\text { and providing various health benefits. }\end{array}$ \\
\hline 8 & $\begin{array}{l}\text { If it has economic value and you agree } \\
\text { to the production of Wedang Uwuh in } \\
\text { Seketi Hamlet, what are your reason? }\end{array}$ & $\begin{array}{l}\text { Mass production can develop SMSE and } \\
\text { increase the income of Seketi Hamlet residents. }\end{array}$ \\
\hline
\end{tabular}

\section{Utilization of TOGA for herbal medicine "Wedang Uwuh"}

Many plants can be used by the people of Seketi Hamlet to improve immunity during the Covid-19 pandemic (Widyanata et al, 2020). Understanding and public awareness of the types of plants that can be used for daily treatment through herbal drinks, namely Wedang Uwuh, are also visible. Medicinal plants are plants that are commonly used as medicine by the community. Once material presentation is over, the people of Seketi Hamlet will gain knowledge and understanding of TOGA. 
The benefits of TOGA for medical treatment have already been widely known by the Seketi community, both before and after the presentation of material during thematic community service activities. the public are mostly familiar with the various benefits of homemade medicinal plants, among others, how ginger can overcome gout, lemongrass leaves are rich in antioxidants, Cinnamon contains anti-inflammatory compounds to reduce risk of cardiovascular diseases, Nutmeg leaves can clean toxins in the liver and kidneys, cardamom and ginger combination can boost the immune system, and rock sugar and ginger combination can relieve coughs and colds (Parvez, 2016).

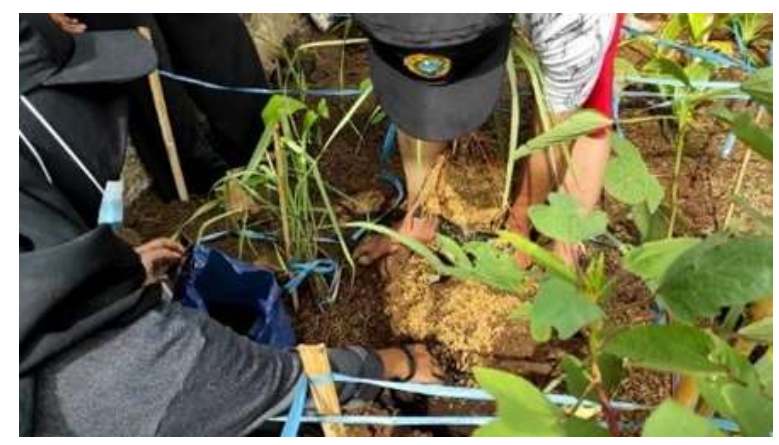

Figure 3. TOGA planting process

The series of thematic community service activities began with the creation of the Seketi Hamlet Health Garden. Furthermore, the implementer empowers the community to take part in activities and participate in utilizing the resources in their environment namely, the manufacture of TOGA planting media. It aims to provide knowledge and skills on how to plant, make and care for TOGA. In addition, this activity is also intended for land utilisation as a growing medium for TOGA which can provide additional income.

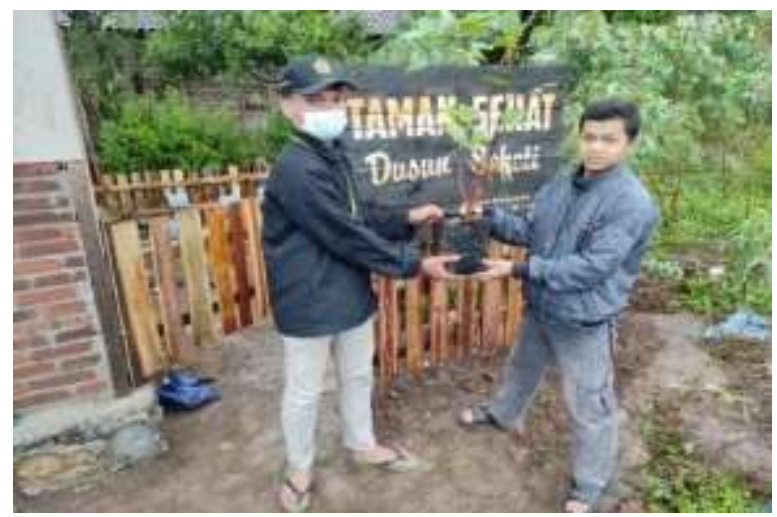

Figure 4. Handover of TOGA to Karang Taruna (youth neighbourhood organization) of Seketi Hamlet 


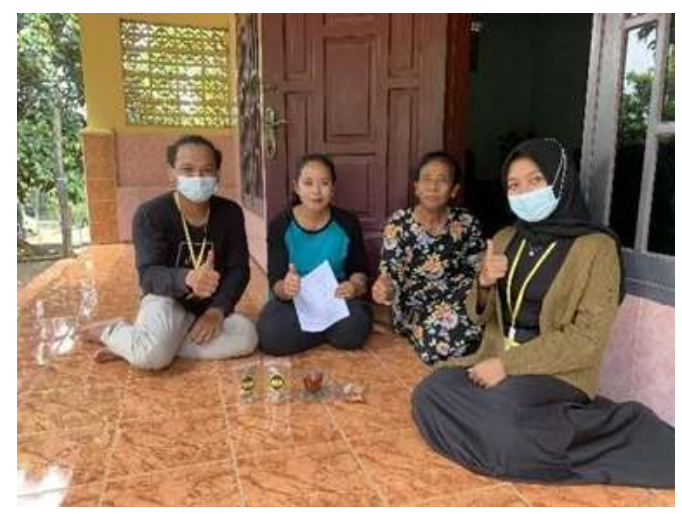

Figure 5. Socialisation of the benefits of TOGA.

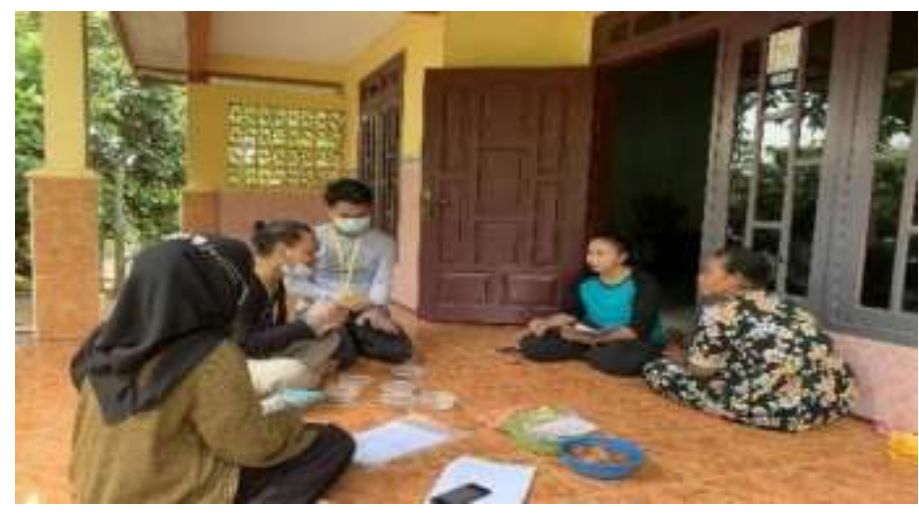

Figure 6. Socialisation of the benefits of Wedang Uwuh.

After the community service group (Figure 4) carried out a work program of fence making and TOGA planting in the Seketi Hamlet Health Garden, the implementer hands the garden over to the chairperson of the youth organization (Karang Taruna). The implementer hands over the garden as a symbolic gesture of the transfer of its ownership to the Seketi community. This was done in the hopes that the community can maintain and care for the health garden. Eventually, the community were able to take advantage of the yields from TOGA planting. Making and serving of Wedang Uwuh herbal was illustrated in Figure 7. 


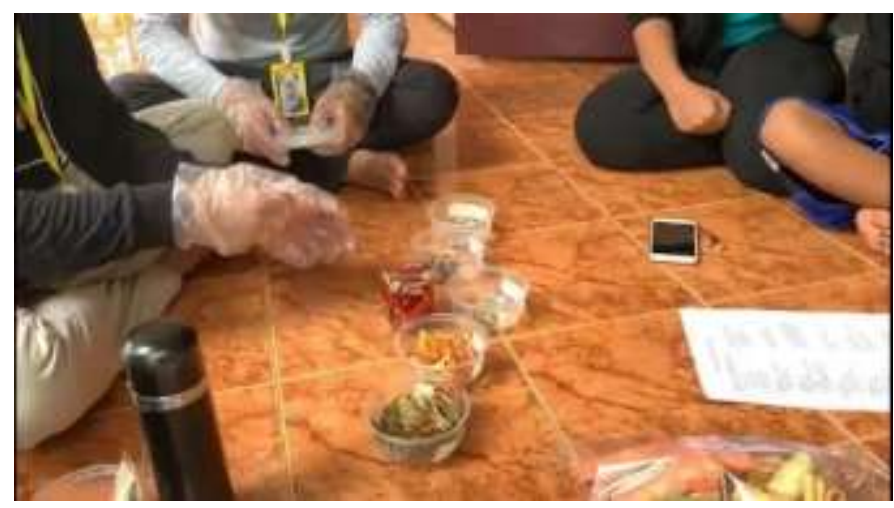

Figure 7. Making and Serving of Wedang Uwuh Herbal Beverages

\section{CONCLUSION}

Based on the implementation of the community empowerment program, the following results were obtained: the Seketi community gained insight into homemade medicinal plants; The people of Seketi acquire skills in the processing of TOGA into herbal beverage Wedang Uwuh to increase immunity (immunomodulators) during the Covid-19 pandemic; increase in Seketi community productivity using their home yards as TOGA planting medium.

\section{SUGGESTION}

Several things must be considered by the apparatus or the Head of Seketi Hamlet namely, the procurement of advanced programs. This program is carried out through entrepreneurship training to create superior products from TOGA. For the people of Seketi Hamlet, it is hoped that they can collaborate in the maintenance of the Seketi Hamlet Health Garden in order to reap long term benefits.

\section{ACKNOWLEDGEMENT}

The implementation team would like to express their gratitude to the Head of Jatidukuh Village, Head of Seketi Hamlet, the neighbourhood administrator, Karang Taruna and the residents of Seketi for their contribution and support during the implementation of the Thematic KKN. The team would also like to thank LPPM Ubhara Surya. The team would like to thank students of group 20 thematic community services batch 1 who had spent their time, energy, and loyalty in the implementation of this community service activity. 


\section{REFERENCES}

Damanik, S. E. (2019). Pemberdayaan Masyarakat Desa Sekitar Kawasan Hutan. Ponorogo: Uwais Inspirasi Indonesia Press.

Damsar \& Indrayani. (2016). Pengantar Sosiologi Perdesaan. Ed.1. Kencana-Prenadamedia Group.

Harjono, Y., Yusmaini, H., \& Bahar, M. (2017). Penyuluhan Pemanfaatan Tanaman Obat Keluarga dan Penanaman Tanaman Obat Keluarga di Kampung Mekar Bakti 01/01, Desa Mekar Bakti Kabupaten Tangerang. JPM (Jurnal Pengabdian Masyakat) Ruwa Jurai, 3(1), 16-22.

Kusuma W., D., Ekasari, W., Witono, J. R., \& Purnobasuki, H. (2016). Toga indonesia. Surabaya: Airlangga University Press.

Mindarti, S., \& Nurbaeti, B. (2015). Buku Saku Tanaman Obat Keluarga (TOGA). Bandung. Jawa Barat: Balai Pengkajian Teknologi Pertanian (BPTP)

Patola, F. M. (2018). Pelatihan dan Pendampingan Budidaya Tanaman Obat Keluarga di Pekarangan. Adi Widya: Jurnal Pengabdian Masyarakat, 2(2): 185-190

Parvez, G. M. (2017). Pharmacological Activities of Mango (Mangifera Indica) : A Review. Journal of Pharmacognosy and Phytochemistry JPP, 5(3), 1-7

Permendesa PDTT 17 Tahun 2019 tentang Pedoman Umum Pembangunan dan Pemberdayaan Masyarakat Desa.

Widyanata, Jerry, K.A., Mayadewi, N.N.A., Cahyaningrum, P.L., Trarintya, M.A.P., Muryani, N. M. S., Daryaswanti, P. I., ... \& Putra, I.G.Y. (2020). PemanfaatanTanaman Obat Keluarga (TOGA) di Masa Pandemi COVID-19. Denpasar:Jayapangus Press Books.

(C) 2021 by authors. Content on this article is licensed under a Creative Commons Attribution 4.0 International license. (http://creativecommons.org/licenses/by/4.0/). 


\section{Original Title:}

Pemberdayaan Masyarakat melalui Budidaya Toga serta Minuman Herbal "Wedang Uwuh” di Dusun Seketi

Abstrak. Pemberdayaan masyarakat desa adalah upaya mengembangkan kemandirian dan kesejahteraan masyarakat dengan meningkatkan pengetahuan, sikap, keterampilan, perilaku, kemampuan, kesadaran, serta pemanfaatan sumber daya. Hal ini dilaksanakan dengan menetapkan kebijakan, program, kegiatan, dan mendampingi sesuai dengan esensi masalah dari prioritas kebutuhan masyarakat desa dalam meningkatkan aktivitas masyarakat melalui budi daya tanaman obat keluarga. Tanaman obat keluarga (Toga) adalah tumbuhan berkhasiat sebagai obat tradisional. Tanaman obat ini bisa dimanfaatkan untuk pembuatan wedang uwuh. Bahan pembuatannya terdiri atas berbagai jenis rempah-rempah, yaitu jahe, cengkih, daun pala, daun serai, kapulaga, kayu manis, kayu secang, dan rosela. Metode yang digunakan dalam pelaksanaan program ini, yaitu melalui difusi ilmu pengetahuan serta praktik langsung. Sasaran kegiatan ini, yaitu masyarakat Dusun Seketi. Hasil kegiatan yang telah dilakukan di Dusun Seketi sebagai berikut: masyarakat mendapatkan wawasan tentang Toga; masyarakat memperoleh keterampilan cara mengolah Toga sebagai minuman herbal wedang uwuh yang dapat meningkatkan daya tahan tubuh (imunomodulator) di tengah pandemi Covid-19; menambah atau meningkatkan aktivitas masyarakat melalui pemanfaatan lahan pekarangan rumah sebagai media tanam Toga. Oleh karena itu, perlu dilakukan beberapa hal yang harus diperhatikan oleh Kepala Dusun Seketi, yaitu pengadaan program lanjutan berupa pelatihan kewirausahaan guna menciptakan produk unggulan dari hasil Toga dan kerja sama masyarakatnya secara berkesinambungan merawat "Taman Sehat Dusun Seketi" sehingga manfaatnya dapat dirasakan secara jangka panjang.

Kata kunci: Pemberdayaan masyarakat, TOGA, wedang uwuh 